\title{
Conceptual Framework and Applicability of National Security: A Case Study of Pakistan
}

* Tayyaba Muzammal, PhD Scholar

** Prof. Dr. Muqarrab Akbar, Professor / Chairman (Corresponding Author)

\begin{abstract}
The first and foremost essential task for any state is to secure its national security and integrity. This paper explores the fundamental essentials of national security such as territorial integrity, internal and external sovereignty, socio-political stability, economic solidity, cultural cohesiveness, and national solidarity. The objectives of this research work are to investigate the significance and applicability of national security for any state. This research is based on content analysis. This case study of Pakistan is selected to investigate the essential elements, internal and external elements of security in Pakistan in the light of the framework of security at the global level. The current study indicated that the notion of National Security had reformed in the 21st century. Now National Security interpretation will be elaborated from different threats such as territorial security, sovereignty, and economic, social, political, and environmental security. The research explores that contrary to external threats, Pakistan is facing internal threats such as political contradictions, ethnic origins, sectarianism, and militant organizations that also troubled the security situation.
\end{abstract}

Keywords: Territorial Integrity, Pakistan, State Sovereignty, National Security

Introduction

National Security definitions and implications range increased in the $21^{\text {st }}$ Century. The earlier concept and notion of a state's national security policy was changed due to wars and skirmishes. Now, hardline force is not limited to military security, sovereignty, and territorial reliability. It encompasses a broad variety of challenges, including economic security, diplomatic, social security, cybersecurity, and environmental security. Due to the multiple concerns of conventional rival India and insecure Afghanistan, Pakistan's geostrategic climate is multidimensional and dynamic. On the other hand, the security and defense structure of Pakistan has been doomed by internal challenges such as racial problems, sectarianism, political instability, weak civilian-military ties, and equipped insurgent groups (Malik, 2015). The security budget is as follows, according to provincial budget documents for 2015-2016: 125.7 billion dollars in Punjab, 55.07 billion dollars in Sindh, 31.5 billion in Khyber Pakhtunkhwa, and 22.7 billion in Baluchistan (provincial budget documents, 2015-2016).

Both idealism and realism school of thoughts are entirely separate approaches; realism favors the use of force and proponents of idealism want to take nonviolent action to guarantee national stability. To describe international security structures, different security models are also applicable, such as the competitive security model focused on Nations, groups and persons, the cooperative security model emphasized only in Nations, international organizations is the main focusing point in the collaborative security model, and the regional security model promoting collaboration in local organizations (Mushtaq, 2011).

\section{National Security: Conceptual Background}

National security analysis is an entry point in international affairs for the advancement of complex powers within the context of international politics. In the 21 st century, the term national security has taken on several repercussions. The national security agenda of the state was not relied on the postCold War scenario to impose hard power to guarantee national security. Military defense, sovereignty, and territorial defense are not limited to national security. A wide variety of challenges have been

* Department of Political Science, Bahauddin Zakariya University, Multan, Pakistan Email: aqeelpk786@yahoo.com

** Department of Political Science, Bahauddin Zakariya University, Multan, Pakistan Email: muqarrabakbar@bzu.edu.pk 
absorbed; they can be political, social, technological, cyber, and environmental. Pakistan's sophisticated and complex geostrategic climate and domestic security situation has made it impossible for it to easily protect national security. Afghanistan's Civil War and the Cold War period had a significant effect on the economy of Pakistan and its culture. Three wars with conventional competitor India, differences with Iran on some issues are also a hallmark of Pakistan's national security dilemma. Naturally, racial, political, social, and sectarian attacks from numerous extremist groups have become serious domestic challenges in nation-building. The national security term has been modified since 11 September 2001. This has been restricted in the past to the capacity of the armed forces to uphold national security and collective integrity.

Figure-: Origin of word Security

Seurte (In French)

Securus (In early Latin)

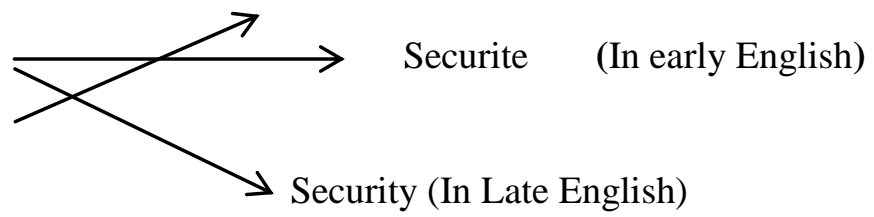

Source: https://etymologeek.com/eng/security

\section{Definitions of National Security}

Researchers and analysts were unable to present an internationally accepted explanation of national security as they have a difference of opinion regarding the idea and concept of national security. A large number of scholars have defined national security to elucidate this concept but the notion of this concept is still unclear and vague. The simplest and traditional definition might be that the freedom of all military threats and political pressures.

Lippman (1943) nation about security is that a state can be secured itself by utilization of power. The state has a legitimate right to defend itself by war to secure its national interests. In the views of Lasswell (1948), protection from external coercion and freedom of foreign dictation is known as national security. According to the theoretical idea of Woofers (1960), the meaning of national security is that there are no threats to the defense system and anxiety about values. In 1973 Trager and Ksonenberg interpreted that safety is a situation that the ruler of the state assumes that the state is unsafe, but it will be safe enough or vice versa. In 1981, Bellany stated that a state is obliged to be securing from coercion and pressures in worldwide relationships. A state may prevent wars by taking effective measures because war or invasion results would be victory or defeat. In 1984, McMillen said that security was a fundamental idea that faced challenges and a mixture of positive perception. Macmillan uniquely saw security as a complement to rather than the psychological orientation of decision-makers. Security is a term to protect or secures the secrets of a state and its people. A state that provides maximum safety against terrorism or espionage is considered a risk or threats Free State (Encyclopedia, Oxford Dictionary, 2015).

\section{Miscellaneous National Security Objectives and Types}

To achieve the national interest, national security aims, and purposes to be set. First is in medical terms. Garrison elaborated on the meaning of security as freedom from threats and anxiety (Encyclopedia, Miriam Webster, 2015). The second is in the legal explanation. Security offers a guarantee of a company or government to provide protection or repayment of the loan in the form of ownership documents. It ensured the utilization of available resources but only for legitimate purposes (Encyclopedia, Your Dictionary, 2015). The third objective of security in terms of computer is that security from internal and external attacks to secure system or network resources. Guarantee for legal purposes would be available for available resources (Encyclopedia, Webster's New World Telecom Dictionary, 2010). The fourth aim of the definition of investment and financing for security is that the company's shares are invested in alternative forms of bonds, investment agreements, investment funds, and variable dividends. In 1933 and 1934 these types of investment and financing guarantees were introduced by legal procedures (Encyclopedia, Webster New World Finance and Investment Dictionary, 2010). 
Figure-: Major Objectives of National Security

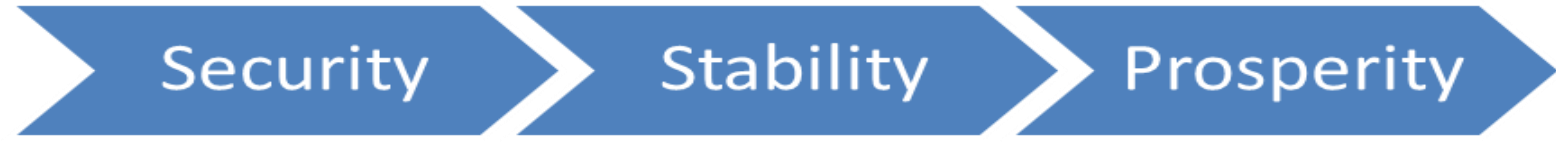

Source: (Khalid, 2016)

The Primary Element of National Security:

In the contemporary era, national security is an essential element of every state. Many researchers have discussed the state security issues. In the early $20^{\text {th }}$ century, Paleri (2008), Joshi (2011), and Manivasakan (2012) also characterized seven key basics of national safety matters; Primary and predominantly basic for national security is regional uprightness. Regional honesty requires free dynamic force, state sovereignty, and powerful control by the legislature and the state. The second requisite is to maintain Socio-Political strength to ensure national security. Most likely, Sociopolitical dependability can't be held with ethnic and religious segregation. A classless society, rule of law, majority rule government, and usage of basic liberties are essentials for Socio-Political strength. The third constituent of public security is monetary solidarity and advancement. The nation that has had the option to give Free-advertise, capable private venture, social soul, and the nobility of work, free and reliable strategies can be guaranteed the financial thriving of any state. The fourth component of state security is ecological equalization. As industry and agribusiness extend, and populace development relies upon biological parity in this way, natural equalization is crucial for endurance.

Social cohesiveness is likewise a fundamental element of public security is the fifth one. The predominant arrangement of rules for social amicability, qualities, convictions, and religions can be drawn from customs, belief systems, and religion. The sixth fundamental of state security is a good profound agreement. Moral solidarity relies upon Patriotism, public objectives and targets are the good and profound agreement. The last basic of state security is safeguarded from external animosity. A sovereign state can forestall outside mediation, dangers, and hostility.

Manivasakan (2012) explains different fixings to guarantee National Security in the 21st century as: a) Diplomacy b) Intelligence Services d) Police e) legal framework, f) Civil Defense.

\section{Interior and Exterior Elements of National Security:}

In the text "Public Security: Imperatives and Challenges ", Paleri (2008), highlights numerous powerful public security components that legitimately influences human life and public security. It doesn't depend on conditions like inward security, psychological warfare, and government-backed retirement, yet it has extended to different parts that can influence national security. He also characterizes the internal as well as external components of national security.

To begin with, political security is an inner part of public confidence. It is the responsibility of any state to safeguard the sovereignty and territorial integrity of the state and the strength of its political framework. Additionally, it extends to law authorization powers and assurance of social arrangement from dangers and unlawful powers. The second component is monetary security that includes financial approach, exchange, business and account, and peaceful accords for exchange. Governmental concerns for poverty alleviation and rejection of income inequality and measures against the oligarchic system to protect the state resources and economic freedom. The third element is the security of natural resources and energy. People can enjoy the necessary energy resources such as oil, gas, water, and minerals without external interference. The fourth element is known as homeland security. This concept is changed subsequently after $9 / 11$ from just border security to other related issues such as airport security, immigration management, transportation security etc. The fifth element is cybersecurity. Cybersecurity can be defined as the Security of data processing infrastructure, computer systems, and operating systems from all kinds of internal and external harmful interference. The sixth element is named as human security. UN presented great contributions to upgrade to define it as public safety from hunger, disease, and suppression. Environmental security is the seventh element. The modern perception of environmental security such as agreements among nations and wakefulness about the impacts of global warming and climate change emerged instead, traditional concepts e.g. water shortage, energy predicaments, and uncertain impacts of climate change. The eighth element is identified as health security. It is a debated and controversial element of national security as several policymakers only supposed it as a threat to national security. The $21^{\text {st }}$ century is a century of advancement that creates awareness about the importance to improve the 
health of citizens. So, now according to the legislative body without health security, a state does not secure its sovereignty. The ninth element is border management that is a major challenge to national security in the $21^{\text {st }}$ century. No doubt, free trade, globalization, and immigration have increased the risk of surveillance and border control. That results in border crimes such as trafficking and illegal migration, smuggling, and terrorist activities (Border Management-PWC, 2015).

Besides, food security, community safety, women, children, and minorities' safety from victimization and discrimination are also an essential element of national security. The basic purpose of all wars and peace talks is to protect national interests. National interests are also a vital element of national security (Danish, 2016).

Figure-: Significant Fundamentals of National Security
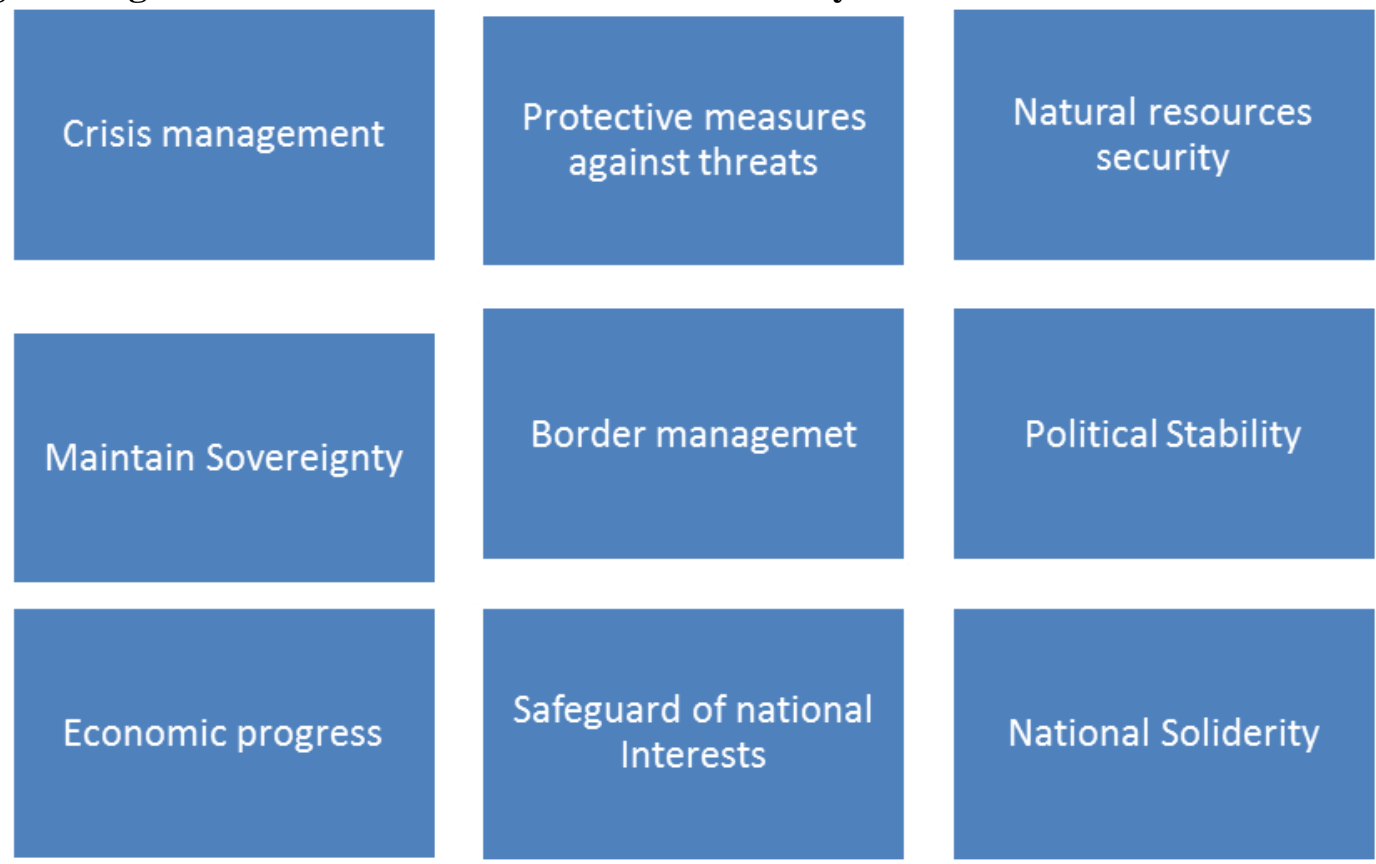

\section{Approaches about National Security}

Source: www.pwe.com

Several researchers have presented miscellaneous perceptions about national security in different methods. State security measures can be explained in different backgrounds and various theories, but in a larger context two classifications are more important; Idealistic approach and Realistic approach (Palmer \& Perkins, 1958).

The first frame of reference believes in power relations and power politics. Hans $\mathrm{J}$. Morgenthau, Plato, G. E. Moore, Waltz, Ayn Rand, E. H. Carr, Hobbes, and Kaplan are prominent thinkers of this approach. The advocates of realism are confident that national security may be safeguarded by using power and ensuring national benefits ((Baylis \& Smith, 2001). Since there are no specific rules and policies in the world wide laws, so, usage of power is an unbeatable option. They also advocate pre-emptive attacks, military capability, balance of power, alertness in war-fare, deterrence, arms race, wars for more power, the security of national interests by hook and crook (Paskins, 2007). Realists think that outside extortions can be decreased by wars so wars are essential evil to minimize threats (Mushtaq, 2011). Analysts also believe that this view has a diverse effect on different states (Ahmed, 2013). Similarly, the United States forced Pakistan to become its ally in the war on terror by applying the theory of offensive realism (Akbar, 2015).

The second frame of reference is liberalism that likes peaceful steps and strategies to maintain national security. They believe that war is an unnecessary arrangement to secure peace and stability. But on the other hand, Robert Nozick, Kries Berg, Schelling, Coser, and Liddle Hart Clauswitz suppose that in critical situations wars and conflicts become important for security. But liberals are against the use of force against fragile states. The major objectives of this theory are democratization, cooperation, human rights, institutionalized peace, international laws, collective security, international organizations, and the global free market. Mushtaq (2011) and Ahmed (2013) argued that U.S. 
realistic counterterrorism policy had become ineffective and counter-productive to check terrorism and coup Al-Qaeda.

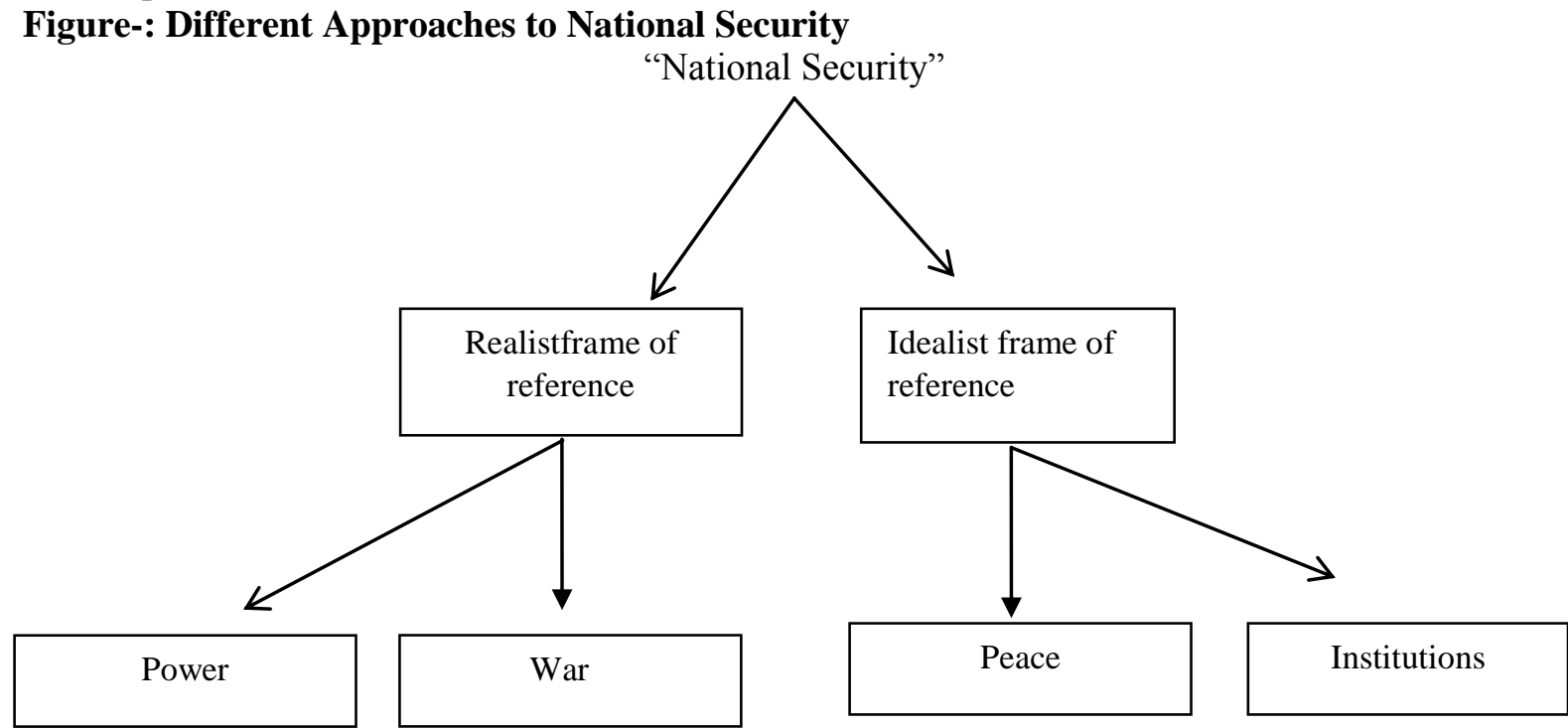

Source: Research scholar

\section{Internationally Recognized Security Systems}

In the International scenario, different security models can be defined as

1- Competitive Security Model

- $\quad$ Supremacy power

- $\quad$ Arms race, dynamic army

- $\quad$ Persons, clusters, countries

2- Cooperative Security Model

- To share common Interests for security

- Deterrence arms -control alliances

- States

- $\quad$ States cooperation for security

3- Collective / International Security Model

- To stop the curiosity of human being for security

- Military/ and economic assistance

- International organizations

4- Regional Security Model

- In favor of passive strategies to ensure states security

- $\quad$ Collective assistance to attain defense \& economic security

- $\quad$ Alliances for economic, political, and cultural promotions

- Regional organizations

5- $\quad$ Peace - Keeping Security Model

- $\quad$ To defend the state against the movement of enemy commands

- Communal defense

- $\quad$ A Peace Keeping Force

- To create an environment of Peace

- $\quad$ To developed environment for regional security (Mushtaq, 2011)

1. The competitive Security Model underscored that the rivalry between different states helps to strengthen their security. Arms race or war can be the outcome of such opposition. The Cold War rivalry between USSR and the US is a pragmatic case of such a security model. The force rivalry is required to acquire world authority on both the Ideological front and regional security. This opposition had separated the global world into two squares (a) socialism (b) private enterprise. Arm race resulted in the large-scale manufacturing of refined weapons: 
atomic weapon, substance armament, organic weapon, and rockets. Combat hardware, philosophical contrasts, and thirst for intensity established the climate of the Cold War. The deterioration of the USSR moved the climate of rivalry towards participation (Mushtaq, 2011).

2. Cooperative Security Model focused on the armed, financial and political participation between states to acquire steadiness and development. This model is not supporting the conflict, armament, war; strife rather requested collaboration for security. Moreover, this model featured reciprocal or multidimensional coalitions of development, diplomacy, arrangements, negotiation, tact, and table converses with maintaining a strategic distance from wars. Common military helps in guaranteed the solidarity to stand against any outside hostility by countering it. An operational example of this model is the European Union that is offering financial, political, and military collaboration for harmony, steadiness, and flourishing (Mushtaq, 2011).

3. The concept of the International Collective Security Model was taken from the notion of Balance of Power. Karen Mingst (1999) in her work entitled "Essential of International Relations" has thrown light on the global aggregate security model. This model has relied on the global community's goal against global security concerns. It is caught in the familiar aphorism "One for all and all for one". With the continuous entry of time, to maintain a strategic distance from clashes and conflicts the United Nations has been composed. The fundamental destination of the United Nations is to tackle issues agreeably by advancing worldwide law and equity and also promote peace. It has the following standards; a) to unravel International dispute b) to monitor and equalization of monetary and military approvals c) to execute International Laws d) to guarantee fundamental human rights assurance across the globe (Mushtaq, 2011).

4. In 1945, Peace-Keeping Security Model was presented by the United Nations to maintain a strategic distance from the third World War. UN set up Peace Keeping warrior's military with the help of world network, so harmony keeping security model rose. Global Peacekeeping powers fill in as an impartial outsider power in the zone of unsettling influence till the settlement of the dispute. This tactic is useful to stop the hostilities between belligerent states, right away. This model was successfully implemented in Congo, Cyprus, and Sudan, and so forth. However, such a model of security is week and cannot work for powerful states (Kegley and Wittkopf, 1999).

5. Regional Security Model characterizes the idea of regionalism. The success of the European Union (EU), North Atlantic Treaty Organization (NATO), Association of Southeast Asian Nations (ASEAN), and Shanghai Cooperation Organization (SCO) from the mid of twentieth century strengthen this model of security. It is different from that of the Provincial security model that emphasizes territorial collaboration among the states of a particular area for the security of these states. This model has been requested by provincial states to frame territorial collaboration for monetary, social, protection, and political dependability. To accomplish the said goals, close affiliation and connections of the states were basic.

According to the U.N Charter (article 52), regional arrangements and bodies are there to address these issues in the context of maintaining international peace and security (Kegley \& Wittkopf, 1999).

Table-: Inter and Intra Regional Security Organizations

\begin{tabular}{ll}
\hline Inter-Regional Security Organizations & Intra-Regional Security Organizations \\
\hline European Union & $\begin{array}{l}\text { North Atlantic Treaty Organization } \\
\text { WARSA Pact }\end{array}$ \\
South Asian Association of Regional Organization & \\
The Association of Southeast Asian Nations. & \\
Shanghai Cooperation Organization. & \\
Mega level (International) & \\
Macro-level(National) & \\
Meso level (Regional) & \\
Micro-level( Individual) & \\
: http://pubs.sciepub.com/seg/1/1/2/index.html &
\end{tabular}




\section{Strategies to Maintain National Security}

Drew \& Snow (1988) referred to five systematic phases to make a genuine national security strategy. These phases are; 1-finding purposes of national security, 2-setting strategies for national security, 3codifying strategy for military strength, 4-drafting operational strategy, 5- appliance operational strategy.

\section{Figure-: National Security Strategy}

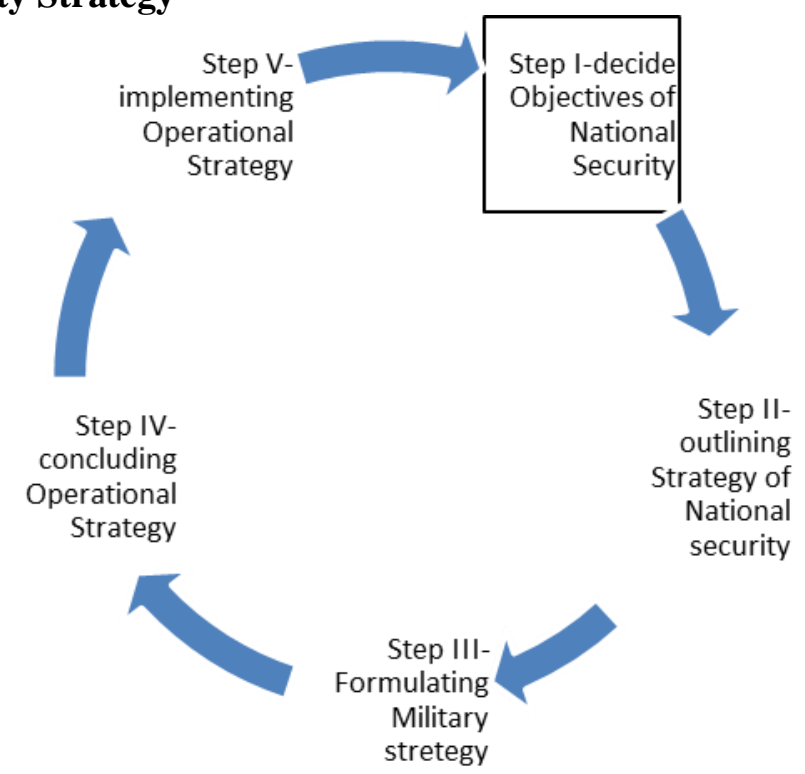

Source: Drew, \& Snow, (1988).

\section{National Security Council of Pakistan}

An advisory body that works under the federal government of Pakistan is known as the National Security Council (NSC) of Pakistan. NSC deals to resolved issues related to national security and foreign policy. The idea of establishing the National Security Council was presented by President Yahya Khan, in 1969. NSC is a platform to guide the ruling government about national security issues, especially foreign policy issues related to security matters of Pakistan. The NSC activities became divisive with the membership from armed forces staff. Organization of the National Security Council of Pakistan comprises of the Army chief, Head of Air Staff, Chief of Staff of the Navy, Executive General of Inter-services Intelligence (Jaspal, 2002). Politicians alleged that NSC would empower the military to interfere in the political issues (Pakistan Institute Legislative Development and Transparency, 2002). General Parvez Musharraf rebuilt NSC by an ordinance, in 2004. The working of NSC was stopped in 2008, but later the 18th Amendment restored its activities.

According to the constitution of Pakistan 1973 Article 152 (A) National Security Council enables one to consult on strategic issues relating to the independence, integrity, and security of the State. Issues related to democracy, government, and harmony among provinces also comes under the jurisdiction of NSC (Chaudhry, 2012).

\section{Table: Configuration of National Security Council of Pakistan}

\footnotetext{
Head: Prime Minister

Consultant: National Security Adviser

Military Consultant: Chairman Joint Chief of Staff Committee

Intelligence Consultant: Director-General, ISI

Military participants: Chiefs of three armed forces

Additional participant: Attorney General of Pakistan, Opposition Leader

Legislative participant: Speaker of National Assembly, Chairman of Senate, Minister of Interior, Minister of Foreign Affairs, Minister of law and justice, Minister of Defense, Finance Minister.

Later, the National Security Council played a significant role to create coordination between the Army and the government. That is essential and imperative to restrain inner and outer security tasks (Ali, 2015).
} 
Table-: Estimated Losses 2001 to 2018

\begin{tabular}{ll}
\hline Year & Billion $\mathbf{\$}$ \\
\hline 2002 & 2.67 \\
2003 & 2.75 \\
2004 & 2.93 \\
2005 & 3.41 \\
2006 & 3.99 \\
2007 & 4.67 \\
2008 & 6.94 \\
2009 & 9.18 \\
2010 & 13.56 \\
2011 & 23.77 \\
2012 & 11.98 \\
2013 & 9.97 \\
2014 & 7.70 \\
2015 & 9.24 \\
2016 & 6.49 \\
2017 & 5.47 \\
2018 & 2.07 \\
Total & 126.79 \\
\hline
\end{tabular}

Source: Economic Survey 2017-2018

Figure-: Internal Security Structure of Pakistan
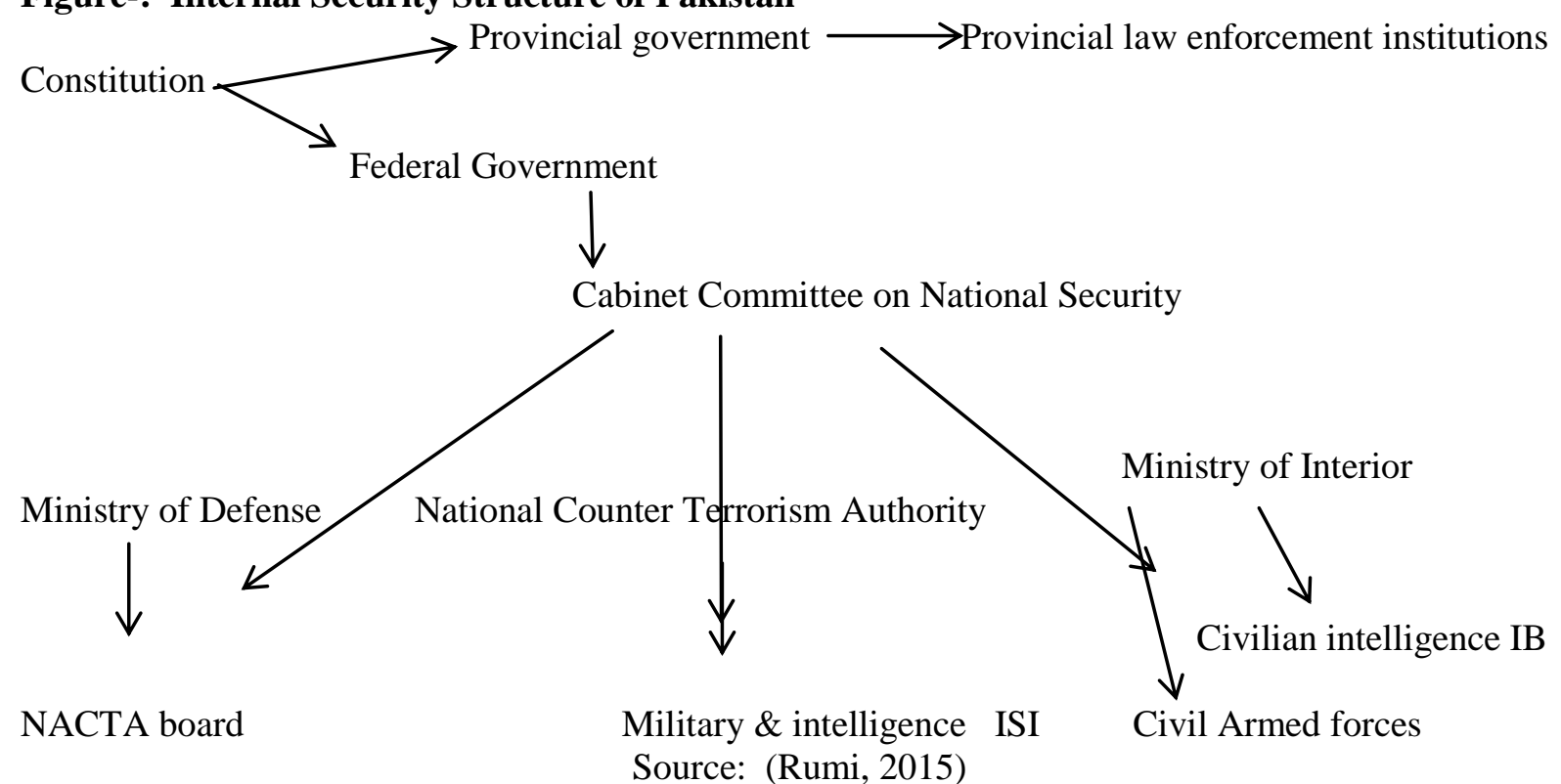

\section{Conclusion}

In the 21 st century, the concept of national security was elaborated and modified according to new situations. The previous idea of the state's national security policy was just security and military that extended into sovereignty and territorial integrity after the Cold War. Now the concept of national security is broader such as political, economic, social, and even environmental security. There were two major types of threats; outside threats and inside threats. Some states use threats to counter the threat. Internal threats are risky and dangerous, which encourages external forces to attack. Pakistan's security concerns are also shaped by the strategic position of the region and international involvements and politics. Terrorism, FATA insurgency, militant culture, terrorist affiliations with enemy states, political instability, bad civilian-military ties, extremism, ethnic conflict, poverty, and worse economic condition are Pakistan's main internal threats. The geostrategic environment in Pakistan is delicate and complicated because of the Indian menace, boundary disputes with Afghanistan, and the US interference in the region. Due to internal and external threats, Pakistan's economic progress is compromised. The constant increase in the security budget of Pakistan depicts 
the picture that Pakistan's security situation is still facing threats from internal as well as external antistate elements.

\section{References}

Ahmed, A. (2013). The thistle and the drone. New York: Brooking Institution Press.

Akbar, M. (2015). A critical analysis of Pakistan's U-turn on Afghan policy after September 11. Pakistan Annual Research Vol. 51, 2015 Journal.

Ali, Y. A. (2015). Pakistan's national security council. Retrieved from https://www.pakistantoday. com.pk/2015/08/10/pakistans-national-security-council/.

Baylis, J., \& Smith, S. (2001). The globalization of world politics: an introduction to International relations, Karachi: Oxford University Press.

Bellany, I. (1981). Towards a theory of international security, political studies. Retrieved from onlinelibrary.wiley.com/doi /10.1111/j.1467-9248. 1981. tb01276.x/abstract.

Border Management PwC, (2015). The future of border management - PwC. Retrieved from https://www.pwc.com/m1/en/publications/.../the-future-of-border.management.pdf.

Chaudhry, M. G. (2012). Constitution of Pakistan 1973. Islamabad: Chaudhry Publication.

Danish, (2016). National interest: meaning, components, and methods. Retrieved from http://www.yourarticlelibrary.com/international.politics/national.interest.meaning.component s.and.methods/48487/.

Drew, D. M., \& Snow. D. M. (1988). Making strategy: an introduction to national security processes and problems. Retrieved from https://apps.dtic.mil>dtic.

Encyclopedia, Merriam-Webster. (2015). Retrieved from http://beta.merriam-webster.com/dictionary/ security.

Encyclopedia, Oxford dictionary. (2015). London: Oxford University Press. http://www.oxforddictionaries.com/definition/english/ Security.

Encyclopedia, Webster's new world finance and investment dictionary. (2010). Indiana: Wiley Publishing, Inc. Retrieved from http://invest.yourdictionary.com/.

Encyclopedia, Webster's new world telecom dictionary. (2010). Indiana: Wiley Publishing, Inc.

Encyclopedia, Your dictionary. (2015). Retrieved from http://www.yourdictionary.com/security\#TX wpbouSwtRzsZrF.99. 1.

Jaspal, Z. N. (2002). National Security Council: implications for Pakistan's political system. Retrieved from http://www.defencejournal.com/.

Joshi, H. G. (2011). Security strategy and regional security arrangements. New Delhi: Forward Books.

Kegley, C. W., \& Wittkopf, E. R. (1999). World politics, trend and transformation. U.S.A: Worth Publishers.

Khalid, I. (2016). Insurgency-counter insurgency: challenge to state security stability prosperity. Lahore: Peace publication.

Khalid, I. (2016). Revisiting Pakistan's national security dilemma. Lahore: Peace Publication.

Lasswell, H. D. (1948). Power and personality.

Lippmann, W. (1943). U.S. foreign policy: shield of the republic. New York: Little, Brown, and Company.

Malik, S. (2015). Pakistan's security problems and challenges in the next decade. Islamabad: NUST Press.

Manivasakan, S. (2012). Security dynamics of India's future relations with Southeast Asian nations paperback. Retrieved from https://www.amazon.com/security-dynamics-relations-southeastnations/dp/8190920782.

McMillen, D. H. (ed) (1984). Asian perspective on International Security, London: St. Martin's Press.

Mingst, K. (1999). Essential of international relations. New York: W.W. Norton \& Company.

Mushtaq, S. (2011). Security perception an overview. Barkley Journal of Social Sciences Vol. 1, No. $10,2011$.

Pakistan Institute of Legislative Development and Transparency, (2002). Retrieved from https://www peaceinsight.org.

Paleri, P. (2008). National security: imperatives and challenges. New Delhi: Tata McGraw-Hill. ISBN 978-0-07-065686-4. 
Palmer, N. D., \& Perkins, H. C. (1958). International relations: the world community in transition. Rawalpindi: National Book Foundation.

Paskins, B. (2007). Realism and the just war. Journal of Military Ethics. ISSN: 1502-7570 (Print) 1502-7589 (Online) Journal homepage: http://www.tandfonline.com/loi/smil20.

Provincial Budget Documents, (2015-16). 2015-16-Finance. Retrieved from finance.gov.sk.ca/ budget2015-16.

Rumi, R. (2015). Charting Pakistan's internal security policy -United States institute of peace. Retrieved from http://www.usip.org.

Trager, F. N., \& Kronenberg, P. S. (1973). National security in American society theory, process, and policy in practice. [Lawrence: Kansas University press]. Retrieved from https://searchworks. stanford.edu/view/784548.

Woofers, A. (1960). National security is an ambiguous symbol. Retrieved from https://www.Jstor. org./stable/2145138. 